\title{
Skill Konseling Dasar Bagi Guru SMK Negeri 1 Nisam
}

\section{Basic Counselling Skills for Teachers at SMK Negeri 1 Nisam}

\author{
Nursan Junita(1)* \& Hafnidar(2) \\ Fakultas Psikologi, Universitas Malikussaleh, Indonesia \\ Disubmit: 06 Desember 2020; Diproses: 21 Desember 2020; Diaccept: 16 Maret 2021; Dipublish: 05 April 2021 \\ *Corresponding author: E-mail: nursan@unimal.ac.id
}

\begin{abstract}
Abstrak
Menciptakan kegiatan belajar yang menarik merupakan tuntutan bagi pendidik untuk menumbuhkan minat belajar peserta didik. Ini menunjukan bahwa tanggungjawab seorang guru bukan sebatas guru mata pelajaran, tetapi mampu meningkatkan minat belajar, dan motivasi berprestasi melalui perannya melakukan bimbingan konseling terhadap peserta didik nya. Permasalahan bolos di akhir jam pelajaran dan kurangnya motivasi belajar merupakan hal yang perlu diantisipasi dan ditelusuri lebih jauh penyebabnya. Banyak hal yang memicu kondisi ini, seperti kurang menariknya metode belajar dikelas, konflik antara peserta didik, permasalahan personal peserta didik sendiri dan ketidakfahaman guru terhadap perubahan psikologis yang muncul pada peserta didik. Berdasarkan hal tersebut penting untuk memberikan ketrampilan dasar konseling pada guru agar mampu memahami peserta didiknya lebih baik. Pelatihan peningkatan soft skill konseling dasar bagi guru SMK Negeri 1 Nisam, dilaksanakan selama 2 hari, yang dihadiri oleh guru mata pelajaran, wali kelas dan guru BK. Pelatihan ini menggunakan metode ceramah, diskusi, role play, studi kasus, serta latihan membuat laporan yang dilanjutkan dengan Praktek lapangan dan pembuatan laporan. Hasil praktek lapangan dilanjutkan dengan pemberian feedback. Hasil dari pelatihan ini diharapkan dapat memberikan pengetahuan dan ketrampilan konseling dasar bagi guru dalam memahami peserta didik secara psikologis, meningkatkan ketrampilan mendengar, ketrampilan bertanya dan ketrampilan observasi. Ketrampilan yang sudah didapat juga akan sangat berguna ketika berhadapan dengan peserta didik. Selain itu ketrampilan ini membantu mengidentifikasikan berbagai permasalahan peserta didik, sehingga peserta didik semakin merasa bahagia pergi kesekolah, minat belajar semakin meningkat, dan motivasi untuk berprestasi juga semakin tinggi.
\end{abstract}

Kata Kunci: Konseling Dasar; Komunikasi Verbal Dan Non Verbal; Ketrampilan Mendengarkan; Ketrampilan Bertanya; Build Rapport

\begin{abstract}
Create an interesting activity is a requirement for a teacher to improve student's interest in study. Means that, teacher is not only as a subjeck teacher, but also has responsible to improve their motivation in learning process by providing guidance and counselling. Problems at school such as truancy at the end of class hours and lack of motivation to learn is need to be anticipated. Many things trigger this condition, such as less attractive method of teaching in the class, conflicts between students and teachers, lack of understanding of schanges that occur in students and unable to establish an effective communication. Based on this isues, it is important to provide basic counseling skills for teachers for having better understanding in their students. The training has been arranged for teachers at SMK Negeri 1 Nisam for 2 days. It was attended by teachers, homeroom teachers and BK teachers. The method that used for this training are the lecture, discussion, role play and case study methods, which are followed by field practice case report discussion and feedback. Furthermore, the results of this training are to give knowledge and basic counseling skill for teacher's as well as to improve their listening skills, questioning skills and observation skills. It also helps teacher to identify the student problems. So that, it will help them feel happy going to school, enjoy learning, and motivating to achieve their goals.

Keywords: Basic Counseling; Verbal And Non Verbal Communication; Listening Skills; Asking Skills; Build Rapport

DOI: https://doi.org/10.51849/j-p3k.v2i1.73

Rekomendasi mensitasi :

Junita, N., \& Hafnidar. 2021, Skill Konseling Dasar Bagi Guru SMK Negeri 1 Nisam. Jurnal Penelitian Pendidikan, Psikologi dan Kesehatan (J-P3K), 2 (1): 14-19.
\end{abstract}




\section{PENDAHULUAN}

Guru mempunyai peran yang besar dalam mengasah minat belajar para siswa nya, sehingga mereka belajar dengan rasa bahagia. Guru juga mempunyai peran yang penting dalam berkreasi agar terbangun lingkungan kelas yang menyenangkan dan menarik, sehingga motivasi belajar anak semakin meningkat. Guru bukan saja bertanggungjawab sebagai guru mata pelajaran, tetapi juga menjadi pembimbing bagi peserta didik. Hal ini penting agar guru dapat memahami kondisi peserta didik secara psikologis.

Berdasarkan berapa literatur mengatakan bahwa proses belajar mengajar membutuhkan interaksi antara siswa dan guru begitu pula sebaliknya, hal ini akan menjadi sesuatu yang bermakna di kelas karena guru merupakan fasilitator dalam memenuhi keingintahuan siswa.

Pada kenyataannya, ada sebagian guru yang hanya memenuhi tugasnya sebagai pengajar saja, dan kurang peduli dengan berbagai perubahan psikologis yang dialami oleh siswanya, sehingga hal ini berdampak terhadap perilaku seperti bolos di jam pelajaran, melakukan tawuran, melakukan kekerasan disekolah dan sebagainya. Dengan demikian, pengetahuan mengenai gambaran psikologis siswa dan bagaimana cara yang baik dalam menanganinya sangatlah penting.

Penelitian yang dilakukan oleh (Dewi, 2019) menyatakan bahwa gaya komunikasi yang baik dapat meningkatkan keefektifan dalam proses pembelajaran siswa. Hal ini juga didukung oleh penelitian yang dilakukan oleh (Malik, 2014) yang menyebutkan bahwa komunikasi yang dilakukan antara siswa dan guru berfungsi meningkatkan kualitas pendidikan siswa. Jadi dapat disimpulkan pentingnya peran seorang guru dalam membangun komunikasi yang efektif, agar mampu memahami kondisi psikologis siswa yang bermasalah disekolah. Untuk dapat memahami psikologis siswa yang ditangani di butuhkan keterampilan guru dalam mengobservasi, mendengarkan, bertanya, sehingga dengan kertampilan tersebut dapat terbangun komunikasi yang lebih baik lagi.

Pada kenyataannya, peran sebagian guru hanya sebatas sebagai tenaga pengajar saja dan kurang mau peduli tentang permasalahan yang berdampak terhadap minat belajar anak. Sehingga muncul lah berbagai masalah pembolosan, tawuran, kekerasan disekolah dan sebagainya. Berdasarkan inilah penting bagi seorang guru untuk memiliki ketrampilan dasar konseling dalam membantu memahami dan menjalin komunikasi yang efektif dengan anak.

Peran konselor sebagai tenaga pendidik dalam menyelenggarakan bimbingan dan konseling melalui layananlayanan di sekolah diharapkan dapat menunjang keberhasilan siswa untuk menjalankan tugas-tugas perkembangannya dengan baik. Salah satu tugas perkembangan siswa yaitu membangun hubungan sosial dengan lingkungan sekitarnya, dimulai dari lingkungan keluarga, lingkungan sekolah serta lingkungan masyarakat. Senada dengan hal tersebut menurut Gladding (2012), masalah yang biasanya dihadapi oleh siswa di kehidupan sehari-harinya yaitu bergesernya keseimbangan dalam menjalin interaksi dengan orang lain. Hal ini dapat dimaknai bahwa hubungan siswa 
dengan lingkungan sosial rentan terjadi masalah.

Berdasarkan temuan penelitian yang dilakukan oleh Zulhammi (2005) kepada siswa SMA di Kota Padang menunjukkan bahwa siswa yang mengalami masalah komunikasi interpersonal berjumlah sebesar 76,19\%, Kemudian dari hasil penelitian Salmita (2010) terhadap siswa akselerasi SMA di Kota Padang menunjukan bahwa masih terdapat siswa yang memiliki masalah komunikasi interpersonal. Selanjutnya hasil penelitian Arliani (2014) menyatakan bahwa frekuensi komunikasi siswa SMA di Kota Padang berada pada tahap kurang baik dengan tingkat pencapaian sebesar $55,2 \%$. Dari pemaparan data tersebut dapat disimpulkan bahwa kemampuan siswa dalam melakukan komunikasi interpersonal masih mengalami gangguan, sehingga perlu untuk dientaskan atau diperlukan pelatihan soft skill yang dapat membantu meningkatkan kepercayaan diri siswa untuk beriteraksi dengan orang disekitarnya.

Permasalahan yang terjadi di SMK Negeri 1 Nisam adalah seringnya peserta didik cabut atau bolos di jam pelajaran terakhir. Kondisi ini akan berdampak buruk bagi perkembangan peserta didik dan proses belajar mengajar jika berterusan. Berdasarkan kondisi tersebut sekolah perlu mengidentifikasikan penyebab kondisi ini terus berlanjut.

Karena itulah guru perlu belajar memahami berbagai macam gaya belajar peserta didik, belajar bagaimana membuat suasana kelas menjadi lebih menarik dan menyenangkan. Guru juga perlu meningkat pengetahuan bagaimana melakukan komunikasi yang efektif, bagaimana menjadi pendengar yang baik, dan bagaimana memahami Bahasa non verbal peserta didik ketika berinteraksi.

Berdasarkan

beberapa

permasalahan yang muncul diatas, maka penting untuk memberikan pengetahuan mengenai ketrampilan dasar konseling kepada guru agar dapat memahami peserta didik secara psikologis dan mengerti hal hal yang perlu dilakukan ketika berinteraksi dengan peserta didik. Guru juga perlu jeli dalam melihat berbagai perubahan perilaku yang muncul atau terjadi pada peserta didik. Kepedulian guru terhadap berbagai macam kondisi yang dialami oleh peserta didik akan membantu menemukan penyebab utama permasalahan yang dialami oleh peserta didik. Sehingga akan terbangunlah keterbukaan dan kepercayaan siswa terhadap guru. Kondisi ini disebut dengan build rappor (membangun rappor), yang akan membantu terbangunnnya Trust antara guru dan siswa, sehingga proses komunikasi yang terbangun akan semakin efektif.

\section{METODE PELAKSANAAN}

Metode pelatihan yang digunakan dalam kegiatan ini berbentuk workshop, yang divariasikan dalam berbagai bentuk tehnik penyampaian seperti, ceramah, sharing, diskusi, tanya jawab, role play, pembahasan kasus, bagaimana cara membuatan laporan kasus dan melakukan praktek lapangan. Praktek lapangan dilakukan setelah berakhirnya pelatihan. Tujuannya adalah sebagai bentuk aplikasi dari pelatihan yang sudah diperoleh. Hal ini penting untuk membantu guru dalam mengidentifikasikan permasalahan dan melihat lebih jauh penyebab utama dari 
permasalahan peserta didik. Untuk praktek lapangan peserta diberikan waktu selama 3 minggu, mencari dan menuliskan laporan kasus yang didapat dengan mengikuti format laporan yang sudah diberikan. Selanjutnya laporan praktek akan dikumpulkan. lalu pihak pelaksana kegiatan akan kesekolah untuk mengambil laporan atau dikirimkan melalui email dan selanjutkan diberikan feedback.

Program kegiatan ini dirancang berkelanjutan dimasa hadapan. Ini tergambar dari pelaksanaan praktek lapangan yang dilakukan setelah kegiatan. Semua peserta diminta untuk membuat laporan kasus praktik lapangan yang akan diberikan feedback oleh panitia pelaksana.

Berdasarkan hasil laporan praktek tersebut, maka akan didapat gambaran secara khusus dan menyeluruh sejauh apa tahapan pemahaman peserta. Hal ini menjadi acuan untuk program lanjutan dari kegiatan pengabdian ini agar program ini dapat terus berkesinambungan. Bagaimanapun Program ini berfokus secara aplikatif dengan tujuan membuat para peserta lebih memahami bagaimana melakukan konseling secara nyata dengan peserta didik.

\section{HASIL DAN PEMBAHASAN}

Kegiatan Pengabdian ini dilaksanakan di SMK Negeri 1 Nisam, Jl. Cot Mambong KM 09 Nisam Kecamatan Nisam, Kabupaten Aceh Utara. Pelaksanaan kegiatan dilaksanakan pada hari kerja sekolah, yaitu pada hari Jumat - Sabtu tanggal 30 - 31 Oktober 2020. Kegiatan ini dilaksanakan selama 2 hari di SMK Negeri 1 Nisam.

Sasaran kegiatan ini adalah guru SMKN 1 Nisam dengan tujuan untuk mendapatkan

pengetahuan

pembekalan

dan mengenai gambaran psikologis anak dan memiliki ketrampilan konseling dasar agar mampu menangani berbagai permasalahan peserta didik sebelum sampai ke guru BK. Kegiatan ini diikuti oleh guru, wali kelas, guru BK dan guru bagian kemahasiswaan. Seluruh guru berjumlah 51 orang, namun peserta yang hadir dalam pelatihan ini sejumlah 35 orang.

Kegiatan dimulai pada 09.30 WIB. Para panitia yang berjumlah 10 orang sudah hadir tepat pada pukul 08.00 WIB, guna menyiapkan keperluan kegiatan di tempat yang telah disepakati bersama. Peserta kegiatan hadir sekitar pukul 09.00 WIB. Sebelum acara berlangsung peserta diminta untuk melakukan absensi pada daftar hadir yang telah disediakan di meja administrasi tepatnya di depan ruangan acara. Acara berlangsung pukul 09.30 WIB dan dibuka dengan lantunan ayat suci AlQuran oleh salah satu panitia acara. Kegiatan dilanjutkan dengan pembukaan dan kata sambutan dari kepala sekolah SMKN 1 Nisam, kemudian diteruskan oleh ketua Pelaksana pengabdian, dan ditutup dengan pembacaan doa yang dipimpin oleh MC acara. Doa tersebut juga bertujuan untuk meminta kesuksesan dan keberkahan acara kepada Allah swt.

Selanjutnya kegiatan inti dari pelaksanaan acara yaitu sesi materi. Penyampaian materi pertama oleh salah satu alumni Psikologi Universitas Malikussaleh yaitu Nora Nurha Dhani, S.Psi, dengan tema pengantar komunikasi.

Selanjutnya penyampaian materi inti oleh tim dosen Psikologi Nursan Junita. B.HSc., MA, Psikolog dan Dr. Hafnidar, S. Psi., M. Sc. Materi diawali dengan 
pendekatan microskill dalam konseling yang diawali dengan kisah tentang "Samurai Berpedang". Cerita ini merupakan inti dari pentingnya konseling dalam proses penanganan siswa di sekolah.

Selanjutnya sesi ice breaking yang berguna untuk mengembalikan semangat dan menghilangkan kejenuhan peserta setelah menerima beberapa materi. Sesi ini dipandu oleh salah satu panitia acara.

Tepat pada pukul 12.30 WIB peserta diberikan waktu ISOMA, sebelum beristirahat peserta diberikan bekal makan siang berupa nasi kotak. Pada pukul 14.00 WIB seluruh peserta berkumpul kembali di ruangan acara untuk melanjutkan sesi acara hingga sore hari.

Pada hari kedua, kegiatan difokuskan kepada role play, pembahasan kasus dan praktik pembuatan laporan. Selanjutnya, peserta dibagi menjadi kelompok kecil yang didampingi oleh panitia. Role play yang dilakukan merupakan aplikatif dari materi yang sudah didapat dihari pertama, yaitu bermain peran sebagai seorang konselor dan sebagai seorang klien.

Setelah sesi makan siang dilanjutkan dengan latihan menyelesaikan kasus. Peserta diberikan 3 kasus berdasarkan kelompok. Lalu setiap kelompok diminta untuk membacakan kasusnya dan mengidentifikasikan kasus tersebut. Lalu mereka diminta untuk berdiskusi didalam kelompok dan menuangkan hasil diskusi dalam form laporan praktek konseling yang diberikan. Selanjutnya masing masing kelompok diminta untuk mempresentasikan hasil diskusinya, dan setelah itu langsung diberikan feedback oleh tim pemateri.
Sebelum acara ditutup, perwakilan dari pihak sekolah memberikan kata penutup dan apresiasi kepada tim pelaksana. Pihak sekolah mengatakan bahwa kegiatan ini merupakan kegiatan yang mempunyai manfaat besar bagi pihak sekolah dan guru. Mereka sangat senang dengan kegiatan ini. selanjutnya semua peserta, pemateri dan panitia melakukan melakukan sesi foto bersama. Acara berakhir bertepatan dengan masuknya waktu salat ashar, yaitu pukul empat petang. Kegiatan berakhir dengan sukses, semoga mendapatkan manfaat, keberkahan dan rahmat dari Allah swt.

Program ini mendapat kan apresiasi yang luar biasa dari peserta dan pihak sekolah. Bagi sekolah program kegiatan pengabdian ini penting sekali bagi para guru agar memiliki ketrampilan konseling dasar. Pihak sekolah berharap sekolah mereka bisa terpilih kembali sebagai tempat pelaksanaan pengabdian dimasa hadapan. Pihak sekolah sangat senang karena mendapatkan ilmu yang berkaitan dengan psikologi. Materi ini merupkan materi yang penting untuk dapat membantu guru agar lebih memahami kondisi psikologi peserta didik.

$$
\text { Hasil dari kegiatan sosialisasi }
$$
pengabdian kepada masyarakat ini khususnya kepada guru SMKN 1 Nisam dapat menambah pengetahuan dan pemahaman tentang psikologis siswa Komunikasi yang efektif diperlukan oleh seorang guru dalam proses belajar mengajar agar dapat mencapai tujuan pendidikan. Peserta acara ini dihadiri oleh seluruh guru yang bertugas dalam proses belajar mengajar di sekolah. Kegiatan ini diharapkan dapat membantu para guru dalam menghadapi berbagi permsalahan 
yang muncul dalam proses belajar mengajar disekolah. Diharapkan melalui pengetahuan skill konseling ini dapat mengasah ketrampilan observasi, ketrampilan bertanya, ketrampilan mendengarkan dan ketrampilan membangun rapport ketika berhadapan dengan siswa. Dan ketrampilan ini, dapat semakin meningkatkan pemahaman guru secara psikologis terhadap perubahan perilaku siswa.

Pelatihan skill konseling ini sangat penting dilakukan agar guru mempunyai ketrampilan konseling dasar ketika berhadapan dengan berbagai permasalahan siswa. Ketrampilan ini juga akan membantu guru untuk lebih memahami siswanya dan merubah pola komunikasi yang tidak efektif menjadi lebih efektif.

Secara keseluruhan, peserta yang hadir dalam dalam kegiatan sosialisasi ini sangat antusias dan begitu ekspresif dengan tema yang dibawakan. Semua peserta fokus dan menyimak materi yang dibawakan oleh pemateri secara lugas dan mudah dimengerti. Hal ini terlihat dari keaktifan peserta selama pelatihan.

Kegiatan ini telah dilaksanakan di SMKN 1 Nisam dengan lancar dan sukses dengan bantuan dari segala pihak yang terlibat. Sehingga para peserta kegiatan merasa senang dengan ilmu dan pengetahuan baru yang diterimanya.

\section{UCAPAN TERIMA KASIH}

Ucapan Alhamdulillah yang begitu besar disampaikan kepada Allah Swt, atas kemudahan dan kesehatan dalam menyelesaikan penulisan ini. Terima kasih kepada semua pihak yang telah berperan dan mendukung dalam proses Pelaksanaan
Pengabdian kepada masyarakat ini yang tidak mampu kami tuliskan satu persatu, terutama kepada LPPM Universitas Malikussaleh, SMK Negeri 1 Nisam, Prodi Psikologi FK Unimal, Tim Pelaksana dan Penunjang kegiatan pengabdian, dan kepada seluruh anggota tim mahasiswa yang sudah bekerja dengan sangat luar biasa dalam mempersiapkan kegiatan ini sehingga pengabdian dan penulisan jurnal ini dapat terlaksana dan tersampaikan dengan baik.

\section{DAFTAR PUSTAKA}

Arliani. (2014). "Pengaruh Komunikasi Interpersonal Keluarga dan Motivasi Belajar Terhadap Hasil Belajar Ekonomi Siswa di SMA Negeri”. Tesis tidak diterbitkan. Padang: Prodi IPS Program Pascasarjana Universitas Negeri Padang.

Dewi, P.Y.A. (2019). Hubungan Gaya Komunikasi Guru Terhadap Tingkat Keefektifan Proses Pembelajaran. Purwadita: Jurnal Agama dan Budaya. 3: 71-78

Gladding, S. T. (2012). Konseling: Profesi yang Menyeluruh. Terjemahan oleh Winarmo \& Lilian. Jakarta: Indeks

Malik, A. (2014). Fungsi Komunikasi Antara Guru dan Siswa dala Meningkatkan Kualitas Pendidikan. Jurnal Interaksi. 3: 168-173

Prayitno \& Amti, E. (2004). Layanan Bimbingan dan Konseling kelompok. Padang: Universitas Negeri padang.

Salmita, N. (2010). "Masalah yang Dialami Siswa Akselerasi SMA di Kota Padang dan Peranan Guru Pembimbing”. Tesis tidak diterbitkan. Padang: Program Pascasarjana Universitas Negeri Padang.

Willis, S. S. (2004). Konseling Keluarga: Family Counseling. Bandung: Alfabeta.

Winkel, W. S. \& Srihastuti. (2007). Bimbingan dan Konseling di Institusi Pendidikan. Yogyakarta: Media Abadi.

Zulhammi. (2005). "Masalah Hubungan dalam Keluarga Siswa dan Upaya Penanganannya (studi SMA Adabiah Padang)". Tesis tidak diterbitkan. Padang: Program Pascasarjana Universitas Negeri Padang. 